\title{
Teachers' Attitudes to Team Teaching in Japanese Elementary Schools
}

\section{Frances Shiobara \\ Kobe Shoin Women's University \\ Keiko Sakui \\ Kobe Shoin Women's University}

Reference Data:

Shiobara, F. J., \& Sakui, K. (2019). Teachers' attitudes to team-teaching in Japanese elementary schools. In P. Clements, A. Krause, \& P. Bennett (Eds.), Diversity and inclusion. Tokyo: JALT.

Team teaching (TT) has been playing an important role in Japanese English education, especially at the secondary school level, since it started over 30 years ago (Reed, 2016). With the expansion of English education at the elementary school level, the impact of TT on English teaching is going to be even greater. This paper explores the current practices in TT by interviewing teachers who have been participating in it in elementary schools. The interviews offer insights from the different perspectives of homeroom teachers (HRTs), Japanese teachers of English (JTEs), and assistant language teachers (ALTs) to show how TT has been conducted in practice. The results imply that TT is a complicated system in which the roles of the three types of teachers are intertwined and are not necessarily clearly defined. The paper offers suggestions for optimizing educational outcomes within the system of TT.

ティームティーチング(T) は、日本の中高等学校の英語教育において30 年以上大切な役割を果たしてきた (Reed, 2016)。 小学校の英語教育の早期化・教科化にともない、Tはこれまで以上に重要な意味を持つと考えられる。本研究は、小学校での

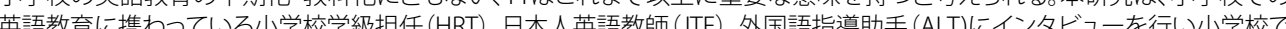

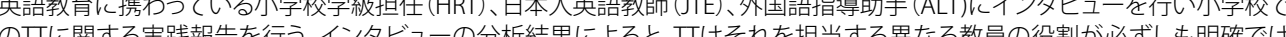
の 唆を提示する。 he Japan Exchange and Teaching (JET) program was introduced into junior and I senior high schools nearly 30 years ago (Reed, 2016) and has contributed to the widespread practice of team teaching (TT) for English classes. Starting in 2020, English education is going to expand at elementary schools when English activities will be introduced to 3rd and 4th graders and English will become a core subject for 5th and 6th graders. Some of these classes will be taught individually by Japanese homeroom teachers (HRTs) and some others will involve team teaching by HRTs with assistant language teachers (ALTs), who are native-English speakers generally hired to work full-time in a number of schools in an area. In addition, some classes will also be taught with the help of Japanese teachers of English (JTEs), who are generally part-time teachers hired to help the HRTs and ALTs with English classes.

There are numerous advantages of TT, such as encouraging cross-cultural understanding, enabling effective presentation of language content, and even on-the-job training for teachers (Tonks, 2006); but there have also been various studies suggesting that TT causes stress for teachers. Igawa (2009) found that some ALTs were anxious about teaching English as many of them were inexperienced and needed feedback from their Japanese counterparts to improve their lessons. Another study that surveyed 282 ALTs suggested that the English language ability of JTEs was one of the biggest problems in TT (Amaki, 2008). In addition, there has been some controversy regarding team teachers' roles (Mahoney, 2004; Sakui, Yamauchi, \& Shiobara, 2017). Mahoney collected open-ended questionnaire data from over 1,400 ALTs and JTEs and found that role responsibilities in TT were not necessarily clearly defined and the different beliefs held by the teachers could lead to negative pressure for both ALTs and JTEs.

Although these studies are informative about the affordances and challenges of TT, much of this research was carried out at the junior and senior high school level. In the run-up to the expansion of English in elementary schools, it will be helpful to focus on teachers who work with younger children in order to determine what challenges they face and how they deal with any problems. This paper will specifically report on the 
perceptions of ALTs, JTEs, and HRTs in elementary schools to illustrate in what ways TT is taking place and how different participants view their roles and teaching practices.

\section{The Study}

Data were collected through detailed interviews with five ALTs (see Table 1), two HRTs, and two JTEs (see Table 2). The ALTs were interviewed in English by the first author who also transcribed the interviews; the HRTs and JTEs were interviewed in Japanese by the second author who transcribed and translated the interviews into English. All interview sessions were audio recorded and each interview lasted approximately one to two hours. Most of the data reported in this paper are derived from these interviews. The interviews were semistructured with several broad questions about English teaching, including their experiences and perceptions about TT (see Appendix A). The interview data were analyzed using grounded theory in which initial categories were created and then further refined as more interviews were conducted.

In addition to the interviews, a total of 32 English lessons in different elementary schools in the Kansai region were observed. These data are not foregrounded in the current paper; however, these observations enabled us to better understand these teachers' experiences and cultural ethos in practice.

Table 1. ALT Interviewees $(n=5)$

\begin{tabular}{llll}
\hline Teacher & Gender & Nationality & Elementary school teaching experience \\
\hline ALT1 & F & Canadian & 5 years \\
ALT2 & F & American & 5 years \\
ALT3 & M & Australian & 2 years \\
ALT4 & F & Irish & 6 years \\
ALT5 & M & American & 6 months \\
\hline
\end{tabular}


I was scared in the beginning to try to talk to the teachers and in the staff room everyone looks busy. No one ever looks available. I always feel rude just going to someone's desk and asking if they have time to talk. (ALT5, 21st February, 2018)

The teacher who had continued in the JET program for the longest period (ALT4) stated that the Japanese teachers are overworked and need to know that the ALT really wants to help them. In order to do this, she offered to help the HRTs grade student work and give feedback on it. It is an unusual situation for ALTs to be grading written work as their job is usually involved exclusively with oral aspects of the English curriculum. The teacher stated that she spent a considerable amount of time doing this but it gave her a twofold benefit. Firstly, the HRTs appreciated that she was actually reducing their workload, and due to this their relationship improved and they were happy to work together on lesson planning and exchange ideas. In addition, she felt that she was benefiting the students, which gave her greater job satisfaction.

\section{Team Teachers Building Rapport and Working Together}

Even if teachers do find time to plan lessons together, it can be difficult to decide who should take the lead in lesson planning. The ALTs reported that they needed guidance on who was to lead a lesson. ALT1 and ALT3 reported that team teachers need to agree on classroom roles as to who takes the lead in which part of the lesson and suggested that a template of classroom roles would be extremely helpful.

Lessons can be planned but teachers also need to be able to anticipate and react to each other's needs. Results of the current study suggest that team teachers need to build up a good relationship so that they can better coordinate with each other in the classroom:

Students are very perceptive, they can see if you are trying to put it on or if it's an actual connection you have. So, if you are actually able to work well with somebody outside of the stressful situation like the classroom, I think it translates well to the classroom. (ALT2, 11th November, 2017)

Most of the ALTs thought that an important factor in building relationships between ALTs and HRTs is how often the teachers meet. Unfortunately, five of the ALTs were not working in one school full-time and rarely met their team teachers. For example, ALT5 teaches at seven different schools in a month. He goes to the same school every Monday but visits the other schools on a rotating system of twice every 3 weeks. He reported that he had a better relationship with the teachers he saw every week. Moreover, ALT4 stated that she had stayed at the same school for 5 years, which enabled her to build positive relationships with many teachers in the school. She had one of the most positive experiences of team teaching.

\section{HRT and JTE Perspectives}

As mentioned above, two types of Japanese teachers are in charge of elementary school English education: HRTs and JTEs. HRTs are government accredited elementary school teachers who are in charge of teaching English as well as other subjects. JTEs are recruited in the community in order to help HRTs teach English and do not have to be qualified teachers. JTEs are usually hired to work part-time or as volunteers, depending on the school district.

\section{Anxiety Among HRTs}

Teacher anxiety is a well-documented issue (Machida, 2016) and it was evident in the current research as well. HRTs expressed anxiety about English becoming a school subject in 2020. When HRT1 was a student in secondary school she studied English in order to pass exams, but at university she made friends with foreign students and travelled abroad. Although she was not a fluent English speaker, these experiences helped her enjoy English and she came to believe that young children would need to have English skills in the future. However, during the interview, she expressed anxiety about her English abilities:

We all studied English in school but we do not have specialized skills and abilities in English. My pronunciation is not correct and I cannot communicate well with foreigners so I feel anxious about teaching English. (HRT1, February 2nd, 2017)

HRT1 remembered one classroom incident that made her feel that she does not have enough English ability to teach English. When an ALT told a short story in class during TT, the children wanted to know what the ALT was saying and looked at HRT1 for some help and explanation. Unfortunately, she could not understand what the ALT had said despite looking up some words using an electronic dictionary in front of the children.

This was a particularly stressful experience for her.

JTE1, who is a fluent bilingual Japanese national married to an American has observed HRTs' anxiety. For example, JTE1 recalls the following episode:

Before the lesson began, I told the HRT that I am going to ask some questions in English in class. Simple English. Then the teacher got really red in the face and started to tremble. I told him to relax but he said he could not speak English. I 
believe some HRTs cannot speak English and feel extremely nervous. I feel sorry for them. (JTE1, January 23rd, 2017)

As these excerpts show, communication problems tend to occur because of HRTs' lack of English abilities.

\section{Constantly Negotiated Roles Among Teachers}

The other theme that emerged in the interview data is the complex role that the three types of teachers play and how these roles are constantly being negotiated. In our observations, it became clear that HRTs, JTEs, and ALTs respectively possess different abilities and power and are also given different privileges. These differences complement each other but create complex systems in which the teachers have to constantly negotiate their roles and their ways of contributing to teaching English. For instance, HRTs are qualified teachers who are expected to carry out English lessons either solo or in TT. Their weakness is their English ability. On the other hand, JTEs cannot conduct a solo lesson because they are not licensed as elementary school teachers, but their English abilities are much higher than those of HRTs. ALTs bring in other qualities and dimensions. HRT1 said that it is very effective for students to listen to ALTs' pronunciation and that ALTs are generally good at promoting fun in class and the children respond very well. At the same time JTE2 said that when ALTs do not understand Japanese and do not adjust their English to the children's level, the lesson does not go very well.

In such a complicated system, both JTEs in the study recognized the HRTs' strong impact on the children and wished that HRTs would participate more in the lessons:

The children already know that I can speak English well. But when a HRT tries to understand what I say in English, the students are very keen to see how the HRT tries to communicate in English. I want the children to see the HRT trying hard to communicate. Then the students will intuitively understand that they do not have to be perfect and communication does not have to be done in a perfect way. (JTE1, January 23rd, 2017)

As the JTEs suggest, the power to lead the children seems to be in the hands of the HRTs and their attitude greatly impacts the children's attitude. However, who takes a lead and who plays what role is not clearly defined and these are being constantly negotiated among the three types of teachers.
The HRTs' confidence seems to be an important factor here. Some HRTs do not mind exposing the fact that they do not possess a high level of English in front of the children. HRT1 suggests that there are quite a lot of individual and personal differences among HRTs concerning to what extent they feel comfortable about their own English abilities. Some HRTs are willing to admit that their English abilities are not high but that they want to try to communicate in English. Others do not want to use English in class or even want to teach younger children, such as first and second graders, so that they can avoid teaching English altogether.

Remuneration Differences Among Teachers

Another factor that increases the complexity is the clear status difference between JTEs and HRTs. JTEs receive very little monetary reward and are expected to work as volunteers in some school districts. For example, JTE1 only receives 1,500 yen per day for teaching three lessons, an amount that does not acknowledge as professional. Similar to the ALTs, JTEs feel they cannot talk to HRTs in the teachers' room because all HRTs seem very busy. In addition, because JTEs get paid only for the time in class, they do not have enough time to plan lessons by themselves or together with HRTs. Finally, HRTs are given training opportunities as a right and privilege although they may not be able attend such workshops easily because of time constraints. Such opportunities, however, are not easily available to JTEs.

\section{Discussion}

The themes that emerged through interviewing ALTs suggest that ALTs would like to have more communication with HRTs and JTEs. This lack of communication causes stress inside and outside of the classroom for ALTs and hinders building a positive relationship between teachers. The Ministry of Education recommends that team teachers work together to plan lessons (MEXT, 2002), but the reality seems to paint a different picture. Leonard (1994) stated that communication between team teachers is the most important factor in developing good rapport but a lack of time to meet and plan lessons is a major factor in limiting such communication (JTU Institute for Education and Culture, 2008; Tsuboya-Newell, 2018). The teachers in this research suggested that it was important to find impromptu opportunities in school or at social events to communicate with team teachers, rather than to rely on formal meetings. In addition, if the ALTs could assist the HRTs and make their workload lighter, the relationship between the teachers could improve and the HRTs and JTEs would have more time to discuss lesson planning. 
Contrary to the findings of Hougham, Walter, and Sponseller (2017) and Leonard (1994) the ALT participants in the current study did not mention language or cultural differences as barriers to communication with the Japanese teachers. However, one of the themes that emerged from interviewing Japanese teachers was that HRTs have anxiety about English teaching due to their perceived lack of English abilities. The HRTs level of anxiety perhaps increases because the burden of communication is shouldered more by Japanese teachers than ALTs, as most communication takes place in English.

As in Hiratsuka (2016), the data show that TT is a very complex matter. Successful English education depends not only on teachers' English abilities but also on other factors that are intertwined in a complex manner and that are being constantly negotiated. Such factors include to (a) what extent HRTs feel comfortable with their own English abilities, (b) what role each teacher plays, (c) ways to stimulate student motivation, (d) how well the teachers understand the students, (e) what kind of a role model as an English learner and communicator the teachers wish to play, and (f) what kinds of abilities and privileges different teachers possess. These issues collectively play a vital role in influencing English education in that "success depends ... on what goes on inside and between people in the classroom" (Stevick, as cited in Stewart, 2015, p. 4).

These challenges are not easily overcome, but perhaps we could suggest that if there were a template that clearly specified who plays which role, it might help each teacher to have clearer expectations in lesson planning as well as in teaching. The current system tends to rely on accidental situational factors, which means that different teachers are thrown into the system and different TT practices emerge based on whose English is better, who has confidence in their English or not, or who happens to get along and have rapport. A better system should be introduced in which teacher roles and routines are more clearly defined. Each teacher or school could work independently towards establishing such a system but probably what is more effective is for the government, either at the Board of Education or central government level, to try to develop such a system.

\section{Conclusion}

The purpose of conducting the research was to assist the three types of teachers in gaining some understanding of the perspectives of their team-teaching partners.

Previous studies have revealed that learners can significantly benefit from the presence of two or sometimes three teachers in the classroom. The Japanese teachers can help with classroom management as well as be good role models for the students. The ALTs can present native speaker pronunciation as well as add to the motivation of students through introducing the culture of their home countries.

However, the TT system seems quite complex in practice. The employment status of each of the three types of teachers is different and this can contribute to a lack of the predictable routines that all teachers need. The current study found that who teaches when and how often is not quite fixed, especially among ALTs and JTEs. Although MEXT suggests that HRTs should be fully responsible for teaching English, their English abilities are not necessarily high enough to accomplish this espoused government goal. ALTs and JTEs, therefore, play a main role in teaching English in spite of their "assistant" status.

This study further found that in spite of the challenges, HRTs, JTEs, and ALTs genuinely want to work well together and communicate better. This is exactly what MEXT proposes as one of the goals for elementary school children in learning foreign languages: that is, to foster a positive attitude to communicate with one another while trying to understand cultural and language differences (MEXT, 2017). It is vital for all teachers to model this behavior by showing willingness to communicate inside and outside of the classroom.

Note. This work was supported by JSPS KAKENHI Grant Number JP16K45678.

\section{Bio Data}

Frances Shiobara is a lecturer at Kobe Shoin Women's University. She has been living and teaching in Japan since 1989. She has been involved in teaching English to elementary school children for the last 30 years. Her main areas of interest are teaching English to young learners and attitudes to technology in education. <fshiobara@shoin.ac.jp>

Keiko Sakui teaches teacher training courses at Kobe Shoin Women's University. She has taught Japanese and English in the United States, New Zealand, and Japan. Her research interests include teacher beliefs and practices, learner motivation, and technology in language education.<ksakui@shoin.ac.jp>

\section{References}

Amaki, Y. (2008). Perspectives on English education in the Japanese public school system: The views of foreign assistant language teachers (ALTs). Educational Studies in Japan: International Yearbook, 3, 53-63. Retrieved from http://files.eric.ed.gov/fulltext/EJ842867.pdf 
Hiratsuka, T. (2016). Actualizing exploratory practice (EP) principles with team teachers in Japan. System, 57, 109-119. https://doi.org/doi 10.1016/j.system.2016.01.004

Hougham, D. G., Walter, B. R., \& Sponseller, A. C. (2017). Practicalities of team teaching: Recent research and experience in Japan. In P. Clements, A. Krause, \& H. Brown (Eds.), Transformation in language education (pp. 135-145). Tokyo: JALT. Retrieved from http://jalt-publications.org/ node/4/articles/6030-practicalities-team-teaching-recent-research-and-experience-japan

Igawa, K. (2009). EFL teachers' views on team-teaching: The case of Japanese secondary school teachers. Shitennoji University Bulletin, 47, 145-172.

JTU Institute for Education and Culture. (2008). An international comparative study on the working conditions of school personnel. Slough, Berkshire, England: National Foundation for Educational Research.

Leonard, T. J. (1994). Team teaching together: A bilingual resource handbook for JTEs and AETs. Tokyo: Taishukan.

Machida, T. (2016). Japanese elementary school teachers and English language anxiety. TESOL Quarterly, 7, 40-66. https://doi.org/10.1002/tesj.189

Mahoney, S. (2004). Role controversy among team teachers in the JET programme. JALT Journal, 26(2), 223-244. Retrieved from https://jalt-publications.org/sites/default/files/pdf-article/ji-26.2art6.pdf

MEXT. (2002). Handbook for team teaching (revised edition). Tokyo: Gyosei Corporation.

MEXT. (2017). The course of study. Retrieved from http://www.mext.go.jp/component/a_menu/ education/micro_detail/__icsFiles/afieldfile/2018/09/05/1384661_4_3_2.pdf

Reed, N. (2016). Pedagogical teacher training for ALTs in Japanese public schools. In P. Clements, A. Krause, \& H. Brown (Eds.), Focus on the learner (pp. 83-89). Tokyo: JALT. Retrieved from http:// jalt-publications.org/node/4/articles/5368-pedagogical-teacher-training-alts-japanese-publicschools

Sakui, K., Yamauchi, K., \& Shiobara, F. (2017). Survey on English education at Japanese elementary schools: Teachers' perspectives. Journal of the Faculty of Letters, Kobe Shoin Women's University, 6 , 49-67. https://doi.org/10.14946/00001969

Stewart, T. (2015). Situating collaboration, team teaching, team learning and innovation in ELT practice. In A. Tajino, T. Stewart, \& D. Dalsky (Eds.) Team teaching and team learning in the language classroom (pp. 3-10). New York, NY: Routledge.

Tonks, B. (2006). ESL team teaching in the Japanese context: Possibilities, pitfalls and strategies for success. The International TEYL Journal. Retrieved from www.teyl.org/article12.html

Tsuboya-Newell, I. (March 13th 2018). Japan's overworked and underpaid teachers. The Japan Times. Retrieved from https://www.japantimes.co.jp/opinion/2018/03/13/ commentary/ japancommentary/japans-overworked-underpaid-teachers/

\section{Appendix}

\section{ALT Teacher Interview Questions}

1. Can you tell us about your teaching experience?

2. How do you feel about teaching English in elementary school?

3. What challenges have you had working in a Japanese school environment?

4. How do you think it is different than working in other school environments you have experienced?

5. What do you think are the biggest challenges for teachers teaching English in elementary school now?

6. How do you think the teachers at your school feel about the possibility of teaching English now or in the future?

7. How do you feel about team teaching with a Japanese teacher?

8. What would be the ideal way to teach English to elementary school children?

9. Do you have any ideas about improving English education in Japan?

\section{HRT and JTE Interview Questions}

1. Can you tell us about your English learning experience as a student?

2. Can you tell us about your experience of teaching English at elementary school?

3. Can you tell us about your experience of TT?

4. Tell us about your perceptions and beliefs of teaching the four skills (speaking, listening, reading, and writing). How do you think they should be taught?

5. Can you tell us about your experience of in-service training for teaching English?

6. What do you think about English becoming a core subject in elementary school?

7. Please share your opinions about English education in general. 